\title{
Random Notes on the Yellow Rail
}

\author{
(Coturnicops noveboracensis)
} By R. D. SYMONS

The Yellow Rail is one of the hardest birds to get to know in all Western Canada. I have enjoyed a nodding acquaintance with this species for over forty years, but I am bound to say that what I have been able to learn about its ways is little indeed.

My first meeting with this shy creature was when I worked on a farm in 1914 at a place about ten miles north-east of Moosomin I was young; my greatest passion was birds; and since in those days no cars, radios, or social activities existed to hinder me, I was able to spend all my spare hours in pursuit of my hobby.

Through the farm ran a grassy draw or shallow watercourse, known as "the Ravine" - which it was not. This draw was carpeted with wire grass, set with wolf willow on its drier edges, and with red willow about the several long, narrow pools of water which persisted all summer and were the residue of the spring run-off. Here I first met the Redwing Blackbird, the Willets and Godwits and the grass sparrows but best of all, the Bobolink.

Books on Canadian birds were not available. in those days, but I had a helper and friend in the late Dr. Speechly, of Pilot Mound, Manitoba, to whom I would write when in doubt, and send small sketches I had made to help him identify them for me. I never met the good doctor, but I remember him with gratitude.

The farmer for whom I worked said to me one day, "Bob, you know all (!) about birds - tell me, what is the one which ticks anway in the evenings around the ravine? It sounds like a great clock." I could not tell him although I had heard the creature myself. Every evening after chores, I lay by the little bit of wild land between the great wheat fields and tried to uncover the mystery of the "tick-tick-tick- - - tick-tick-tick" repeated monotonously from the grass. Sometimes apparently near, sometimes far away, the sound became part of the whole scene - the purpling shadows, the sparkle of water, the nodding grasses. Each night I returned to the farmhouse disappointed.

Haying time came, and the bird for somehaw I was sure it was a bird - gradually ceased to utter its strange note. Now the shallow valley was neatly moved between the pools and among the willow clumps. And then one evening, as I finished topping off a hay cock, something like a young bird ran from between my feet with wings half-opened and looking from side to side as if seeking cover. I clanged my fork on the ground and the bird, to my surprise, took to weak flight with trailing legs. but dropped into a thicket after a few yards of floppy progress. From its flight I knew it to be a rail. The absence of any more tail than a tuft had given it the juvenile appearance. But what kind of rail? I knew the Sora both in flight and on land, but this was no Sora.

Had I been in a Sussex clover field I would have said it was a landrail (corncrake) It was buffy and mottled like that bird. but probably smaller, with two distinguishing features - - rich chestnut undertail coverts, and a white patch on the secondary flight feathers. Now, I argued to myself, this must be the "slough clock" that puzzled the farmer and myself. For the notes heard all spring followed much the same pattern as the Corncrake's, and if my bird's habits were like the Corncrake's, then it was no wonder I had not seen it in the long grass.

I called to mind everything I could remember about the Corncrake, which was not much, as in the Sussex of my early youth that species had already become rare. It was an achievement to see one, for the bird preferred to creep into and through long grass and grain, rather than to take wing. I had seen one flushed by a mower, as the machine swallowed the last round, and it had flown but a few rods before it dropped into the concealment of a heavy swath. I remembered, too, the monotonous "crex-crex-crex" heard from 
a grass field on a warm summer's evening, and recalled that the direction from which the notes came was hard to determine, sounding sometimes near, sometimes far, now from this direction, now from that.

So my strange bird was a small rail, even more shy and reluctant to flush than the Sora, in colour and habits very similar to the English Corncrake, resembling it too in its predilection for a drier habitat than is usually associated with rails. As for the notes "click-click" or "crexcrex", they had the same monotonous repetition and ventriloquistic effect. It evidently spent its whole life in the grass and presumably nested there. Like other rails it was probably semi-nocturnal in its habits, hence the notes heard only in the evening. So off to Dr. Speechly went my letter and back came the usual kind reply: "Your bird is probably a Yellow Rail, and I hope you find out more about it, as I only know it from books myself."

The Great War put an end to looking for Yellow Rails. When that was over I went to the Chilcotin cattle country for a while, but I neither saw nor heard a Yellow Rail there. In 1924 I was back in Saskatchewan, looking after cattle in the Arm River Valley east of Davidson. Here I heard the bird quite often and once flushed one. I also found a nest, which had been badly trampled and the eggs crushed. This nest was on the remains of an old haystack where cattle had bedded down.

About 1930 I happened to mention this to Mr. Mitchell of the Museum staff' at Regina. At that time I was at Battleford, and Mr. Mitchell suggested I try to find the Yellow Rail there, and if possible get a specimen for the Museum. In 1934 I was successful in taking a male bird in breeding season at Nelson's flats south-east of the "Old Town". The birds were quite numerous here, and on a quiet evening one could hear them "clicking" all around, but not a tremble of a grass tussock revealed their exact whereabouts. One specimen was finally obtained by having two friends drag a 60-yard weighted gill net through the grass where the birds were. This finally flushed one which was shot. The

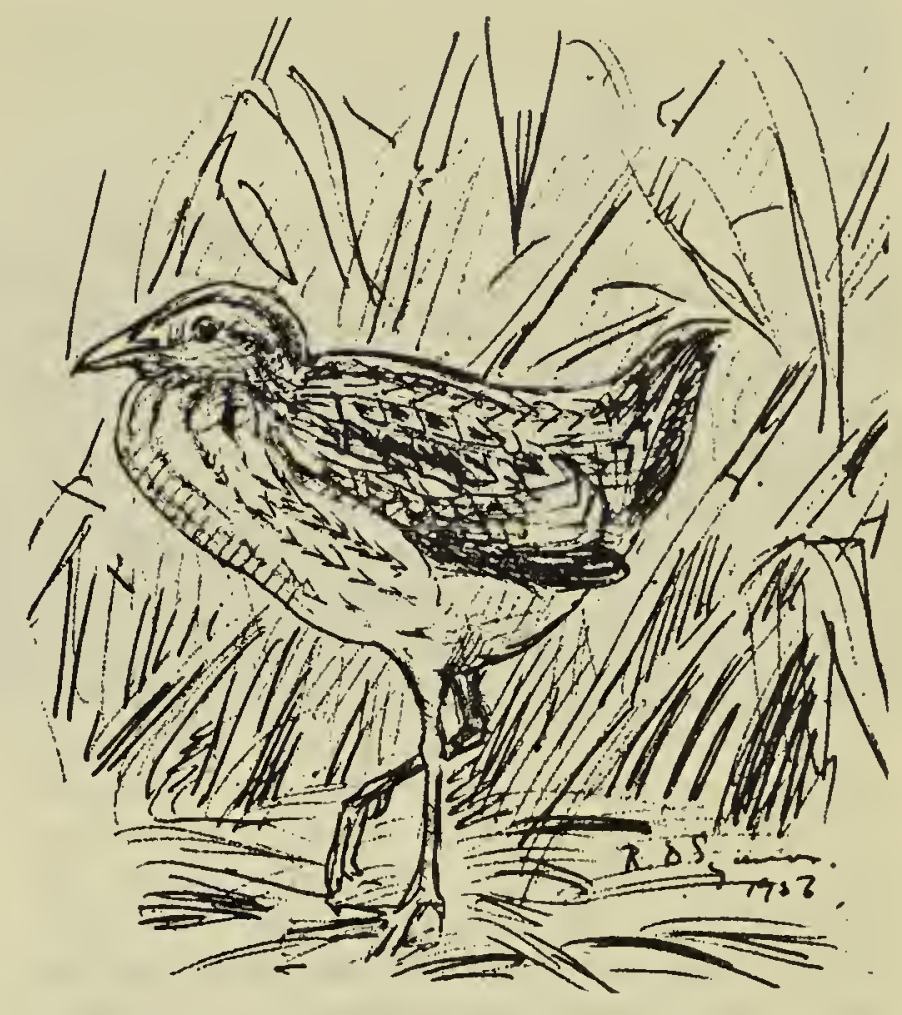

-Sketch by R. D. Symons

skin the second taken in Saskatchewan - was sent to the Provincial Museum.

Later, Mr. Bard and I together visited several areas in the Battleford districi where I had located these birds - Nelson's flats at Battleford, Lamotte's swamp north of Jackfish Lake, and Scentgrass Creek near Iffly on Miller Craig's ranch. Although we heard them with exasperating frequency at all these places, we failed to find a nest, flush a bird, or obtain more specimens. I found this bird (by ear mostly) all the way from Saskatoon to Lloydminster and north to Midnight Lake. Later still my work took me to the Pasquia Hills country; I failed to find them in the hills but heard one on the Pas meadow in Manitoba.

Recently I have made my home in the foothills of the Peace River Country of British Columbia about 500 miles north-west of Edmonton. I have heard a Yellow Rail twice at Charlie Lake, near Fort St. John, where there is an area of grass tussocks at the south end; but nowhere else in the Peace River Country, although I have had no opportunity of carrying on studies in Alberta. I believe the bird has been noted at Great Slave Lake, so no doubt it is very widely spread, at least east of the mountains.

So here is a challenge to somebody - perhaps you? - to track down the full life cycle of this shy 
bird, the Yellow Rail. And may that somebody have the time, the patience, and what I did not have the finances.

Editor's Note: The Museum has records of two specimens in addition to the one received from $R$. D. Symons. One, taken at the north end of Last Mountain Lake in 1932 by Bert Lloyd, went to the Carnegie Museum, Pittsburg. The other, received from Ronald Hooper of Somme, July 13, 1954, is in the Museum at Regina. This specimen was one of two birds taken by the Hoopers in a large marsh at the confluence of the Bowman and Shand Creeks, where they flushed Yellow Rails on. June 8 (3) and June 10 $(12+)$. The stomach of one rail contained the remains of several beetles (one apparently belonging entirely to the Byrrhidae); the other, two small snails, two predacious diving beetle larvae (Water Tigers), and three small seeds. Another report of the occurrence of the Yellow Rail comes from E. M. Callin who has records of them heard (not seen) in the marsh at El Capo Lake and again at Round Lake.

\section{News from the REGINA NATURAL HISTORY SOCIETY}

By MARIE ROBINSON, secretary

Signed, sealed and delivered! Yes, at last the Regina Natural History Society has title to the property on which, ten years ago, they began the creation of a wild life sanctuary. This is a long-time dream come true and there are many exciting plans in the offing for the development of our "Hidden Valley" sanctuary.

A big event in our 1955-56 seasnn was the presentation of life memberships to Mrs. Betty Flock and $\mathrm{Mr}$. Jack Taylor. Both Betty and Jack were original members when the society was founded and have been very active, inspiring workers ever since.

We are happy to announce that the "World Wandering" nature shows being sponsored by our society are a huge success. These shows, which are open to the general public, are being featured in the Museum auditorium every Sunday during the win- ter months. Owing to the crowds that were being turned away every Sunday afternoon, we now have two shows, one at 3:30 p.m. and one at 8:30 p.m. Our president, Mr. Frank Brazier, deserves a great deal of credit for the effort he put forth in obtaining and assembling such outstanding, facinating, educational films. The Saskatchewan Museum of Natural History has also been most cooperative in this endeavor and we hope that, owing to this series of shows, many people will have become better acquainted with their new museum and will also have acquired a keener appreciation of the wonderful world we live in.

\section{SASKATOON NATURAL HISTORY SOCIETY}

\author{
MRS. J. GERRARD
}

The first general meeting of the newly-formed Saskatoon Natural History Society was held in the Physics building, University of Saskatchewan, January 26, with more than 60 people present. The guest speaker was Dr. R. W. Nero, Assistant Director of the Saskatchewan Museum of Natural History, who spoke on Bird Behaviour with particular reference to a colony of Red-winged Blackbirds.

The Executive Committee of the Society consists of: President, Dr. R. M. Bremner; Vice-president, Frank Roy; Recording and Corresponding Secretary, Mrs. John Gerrard; Membership Secretary and Treasurer, Glen Burgess; ex-officio Directors, Dave Robinson, Dr. L. G. Saunders, Dr. S. Houston:

The annual membership fee is $\$ 1.50$ which includes a compulsory subscription to The Blue Jay. The fee for family membership is $\$ 2.00$. If anyone would like to join the society Glen Burgess, 43 Community Apartments, Saskatoon, will be glad to receive subscriptions.

Raven's nest south of the Churchill River. - Mr. Czartoryski of Regina reported to the Museum on November 28, 1955 the finding of a Raven's nest in a ravine off a small lake, south of the Churchill River, in the early summer of 1955, by Emal Wurzycki, a La Ronge prospector. The nest was on a rocky ledge. 